\title{
Peri-Implant Crestal Bone Loss: A Putative Mechanism
}

\author{
Yuko Ujiie, Reynaldo Todescan, and John E. Davies \\ Institute of Biomaterials Biomedical Engineering and Faculty of Dentistry, University of Toronto, 164 College Street, Room 407, \\ Toronto, ON, Canada M5S $3 G 9$
}

Correspondence should be addressed to John E. Davies, davies@ecf.utoronto.ca

Received 26 May 2012; Accepted 14 July 2012

Academic Editor: Michael E. Razzoog

Copyright () 2012 Yuko Ujiie et al. This is an open access article distributed under the Creative Commons Attribution License, which permits unrestricted use, distribution, and reproduction in any medium, provided the original work is properly cited.

\begin{abstract}
Purpose. The immunological mechanisms of peri-implant crestal bone loss have, hitherto, not been elucidated. We hypothesized that bacterial products from the microgap cause upregulation of cytokines in otherwise healthy peri-implant cells, which results in osteoclast formation and, ultimately, in bone resorption. Materials and Methods. We used RT-PCR and ELISA to assay mediators of osteoclastogenesis in rat and human macrophages ( $\mathrm{r}$-and hMO); bone marrow derived stromal cells ( $\mathrm{r}$-and hBMCs); and human gingival fibroblasts (hGF) — with or without stimulation by LPS. TRAP positive multinucleate cells were assessed for their resorptive ability. Results. We show that IL- $1 \alpha$, IL- $1 \beta$, and IL- 6 were expressed by all examined cell types, and TNF- $\alpha$ was upregulated in hGF. Secretion of IL- $1 \alpha$ and IL- $1 \beta$ proteins was stimulated in hMO by LPS, and IL- 6 protein secretion was highly stimulated in hBMCs and hGF. Both LPS and RANKL stimulated macrophages to form osteoclast-like TRAP positive cells, which resorbed calcium phosphate substrates. Conclusion. Taken together, the results of our study support the hypothesis that bacterial endotoxins upregulate enhanced mediators of osteoclastogenesis in resident cells found in the healthy peri-implant compartment and that the local synergistic action of cytokines secreted by such cells results in the genesis of resorptively active osteoclasts.
\end{abstract}

\section{Introduction}

Dental implants facilitate the rehabilitation of edentulous patients, and markedly improve both function and esthetics. However, crestal bone loss on the order of $1.5 \mathrm{~mm}-1.6 \mathrm{~mm}$ has been observed radiographically around some dental implants within the first year of loading $[1,2]$. The connection of the abutment to the endosseous component in twostage systems invariably results in a microgap $(10-50 \mu \mathrm{m})$, which communicates with the much larger residual cavity created between the abutment screw and the internal implant wall. Previous evidence has shown that Gram-positive, and Gram-negative bacteria found in the oral cavity can colonize the inner surfaces of implants and the microgap area [3-5]; and cause inflammatory reactions in the peri-implant soft tissues. Furthermore, in a fascinating study Zipprich et al. [6] have shown that cyclical loading of the implant/abutment interface can result in the pumping of the liquid contained in implant cavities into the peri-implant compartment.

The existence of an inflammatory cell infiltrate at the level of the implant-abutment junction-even around implants placed in areas of meticulous plaque control and clinically healthy, soft tissues-has been described in a series of animal studies [7-10]. However, other pre-clinical studies have reported a significant reduction in both inflammatory cell infiltrate and bone loss in both one-piece implants (compared to conventional two-piece implants) and designs in which the abutment/implant interface has been changed $[9,11]$. Thus, it has been suggested that the microgap in two-piece implants plays a key role in the generation of an inflammatory cell infiltrate, and crestal bone loss, [12] through effects on hard and soft peri-implant tissues [13].

Broggini et al. demonstrated that in dogs, the major cell type constituting the inflammatory infiltrate around the microgap of submerged and nonsubmerged two-piece implants was the neutrophil [9]. In their experiment, while there was no selective neutrophil accumulation and a significant reduction of mononuclear cells adjacent to onepiece implants, the population of mononuclear cells was significantly increased around two-piece implants. Another study, in monkeys, showed an inflammatory cell infiltrate containing mostly lymphocytes and plasma cells in two-piece implants [14].

The pathophysiological consequences of the implantabutment interface position have clinically important implications, since esthetic demands encourage the placement of 
implants in a more apical position [15]. Such placement could promote inflammation and bone loss, gingival recession, and esthetic failure. Relative to the original alveolar crest position, implants placed on the crestal or subcrestal level have demonstrated greater bone loss than implants placed supracrestally $[13,14,16]$. Additionally, experiments with subcrestal implant interfaces showed a significantly greater density of neutrophils than did supracrestal interfaces [10], but the size of the microgap was not a contributing factor in crestal bone resorption [12, 17]. A prospective clinical trial has identified a similar relationship between the location of the interface and the magnitude of bone loss [18], which ratifies the findings described above. In this clinical investigation, when the implant interface was positioned close to the original alveolar crest, greater bone loss occurred in comparison to implant interfaces placed more supracrestally. Thus, the location of the interface is an important determinant of alveolar bone loss in humans, as has been described in initial observations [19] and previous animal studies $[20,21]$.

It is widely known that bone matrix is resorbed by osteoclasts, which are multinucleated giant cells that originate from hematopoietic progenitors of the monocyte/macrophage lineage [22]. It has been reported that lipopolysaccharide (LPS) can induce bone resorption $[23,24]$ and osteoclast formation [25]. LPS supported the survival of preosteoclasts (mononuclear osteoclasts) through $\mathrm{NF}-\kappa \mathrm{B}$ activation independent of host factors such as PGE 2 , RANKL, IL-1, and TNF- $\alpha$ [26]. Osteoclast formation can be modulated by IL$1 \beta$ and TNF- $\alpha$ while enhancing the expression of RANKL [27]. LPS derived from different sources has been employed to specify an effector mechanism relevant to dental implants. Thus, while Tesmer et al. have shown that certain dental implant designs contribute to the development of multiple colony forming units for both A. actinomycetemcomitans and P. gingivalis [28], Koutouzis et al. [29] employed E. coli bacterial culture solution to demonstrate that implant design affects invasion of oral microorganisms into the fixtureabutment interface microgap under dynamic-loading conditions.

Thus, it has been shown that inflammatory cells, microbial cells and/or fluid $[8-10,14,30]$ are associated with the implant-abutment interface. [10, 12, 14, 16] Nevertheless, the putative correlation between the microgap presence and crestal bone loss has remained refractory to mechanistic explanation. Consequently, the purpose of the present study was to investigate the possible mechanisms of crestal bone loss around dental implants using a bacterial endotoxin model in vitro.

We hypothesized that bacterial products originating from the microgap cause the upregulation of cytokines, in healthy peri-implant macrophages, mesenchymal stromal cells and gingival fibroblasts that result in the recruitment of resorptively active osteoclasts and, ultimately, bone resorption. The notion that healthy fibroblasts in the periodontium could play an important role in providing sustainable inflammatory mediators in the transition from gingivitis to periodontitis has also recently been discussed [31], although such cells would not be expected in the peri-implant compartment. Thus, in order to address our question, we started with the premise that the peri-implant tissues surrounding the microgap are normal and healthy at the time of healing abutment connection. We further assumed that bacterial products would act on cells in the suprabony soft tissue, and thus we investigated the effect of LPS on cytokine expression and secretion in macrophages, stromal cells, and gingival fibroblasts. To qualify our LPS model, we first undertook some comparative studies to assess the effects of laboratory produced, Porphyromonas gingivalis ( $P$. gingivalis), Prevotella intermedia ( $P$. intermedia), and commercially available, Escherichia coli (E. coli), LPS on human gingival fibroblasts, since concern has recently been raised over the use of "home made" LPs preparations [32].

\section{Material and Methods}

2.1. Preparation of Human Gingival Fibroblasts ( $h G F s$ ) from Gingival Tissue. Samples of gingival tissues were obtained, with informed consent, from 5 patients who showed no clinical signs of periodontal disease. The tissues were collected from different sites: (1) the palate, used for free connective tissue gingival grafting; (2) the marginal gingivae, following extraction of third molars; (3) the gingiva around dental implants during 2 nd stage surgery. The collected tissue was washed 3 times with $\alpha$-MEM supplemented with Penicillin G (167 units $/ \mathrm{mL})$, Gentamicin $(50 \mu \mathrm{g} / \mathrm{mL})$, and $10 \%$ FBS, following which it was cut into small pieces and digested with a mixture of $3 \mathrm{mg} / \mathrm{mL}$ collagenase type 1 (Sigma-Aldrich) and $4 \mathrm{mg} / \mathrm{mL}$ Trypsin in SM for 1 hour at 37 degrees. The digested tissue was centrifuged for 5 minutes at $1150 \mathrm{rpm}$, and the supernatant was discarded. Then, $10 \mathrm{~mL}$ of SM was added to the tube containing the pellet, and the cell suspension was transferred to a T-75 culture flask. When cells reached $80-90 \%$ confluence, they were passaged to new T-75 flasks and plated at a concentration of $1.0 \times 10^{6} \mathrm{cells} / \mathrm{cm}^{2}$ in 6-well plates at Passage 3 . This procedure was repeated five times.

2.2. Human Macrophages (hMO). Two healthy volunteers, a 35-year-old female and a 50-year-old male, donated blood for this experiment, after providing informed consent. Venous blood $(30 \mathrm{~mL})$ was collected from a brachial vein into heparinized tubes and immediately processed. Peripheral blood mononuclear cells (PBMC) were isolated using gradient centrifugation in Histopaque solution (Sigma-Aldrich). Isolated PBMCs were incubated in RPMI (Roswell Park Memorial Institute) medium-1640 (Gibco) with 10\% FBS in 6 well-plates at a density of approximately $5 \times 10^{6} \mathrm{cells} / \mathrm{cm}^{2}$ in a final volume of $2 \mathrm{~mL}$. The cells were allowed to adhere to plastic dishes for 90 minutes at 37 degrees, $5 \% \mathrm{CO}_{2}$, in RPMI medium. The cells were vigorously washed with PBS three times, and the nonadherent cells (mainly lymphocytes) were removed. Cell viability was $91 \%$ before cells were seeded and characterized by immunofluorescence analysis with Human anti-CD14, Human MHC II, and FITC-conjugated Mouse IgG (all from BD Scientific).

2.2.1. Human Bone Marrow Cells (hBMCs). hBMCs were obtained, following local Research Ethics Board (REB) 
approval, from the collection kit filters (Baxter, Deerfield, IL, USA) normally discarded following harvesting of bone marrow, from healthy donors, for transplantation. The cells were washed with PBS and then plated in $75 \mathrm{~cm}^{2}$ flasks in $10 \mathrm{~mL}$ of SM. Cultures were incubated at 37 degrees with $5 \% \mathrm{CO}_{2}$. After 24 hours, non-adherent cells were removed. When cells achieved 70-80\% confluency, they were trypsinized (0.25\% trypsin in PBS at 37 degrees for 5 minutes), harvested, and expanded in new $75 \mathrm{~cm}^{2}$ flasks. Cells were expanded to achieve $80-85 \%$ confluency at Passage 1 through Passage 4. At this stage, no hemopoietic lineage cells were detectable. The hBMCs were suspended in SM and seeded at a concentration of $1.0 \times 10^{6} \mathrm{cells} / \mathrm{cm}^{2}$ in 6 well plates at Passage 4. We collected filters from six different donor aspirates and repeated the hBMCs culture procedures six times.

2.3. Mouse Macrophages (RAW 264.7) ( $m M O$ ). The mouse macrophage cell line, RAW 264.7 (ATCC, Manassas, VA, USA), was initially suspended in fresh supplemented medium (SM) composed of $10 \%$ fetal bovine serum (FBS) (Hyclone, Logan, UT, USA), 80\% DMEM (ATCC) and 10\% antibiotics (167 units/mL Penicillin G, $50 \mu \mathrm{g} / \mathrm{mL}$ Gentamicin), and $0.3 \mu \mathrm{g} / \mathrm{mL}$ Fungizone (all Sigma-Aldrich, St. Louis, MO, USA). Subsequently, the cells were plated in $75 \mathrm{~cm}^{2}$ (T-75) polystyrene tissue culture flasks (BD, Franklin Lakes, NJ, USA), and incubated at 37 degrees with $5 \% \mathrm{CO}_{2}$. The medium was replaced every 2 or 3 days. The cells grew to $80 \%$ confluency, as observed by inverted phase microscopy, after which they were washed with PBS (Gibco, Carlsbad, CA, USA) and removed from the culture flask after the addition of $2.5 \mathrm{~mL} 0.25 \%$ trypsin (Gibco) in PBS for 5 minutes at 37 degrees. To inactivate the trypsin, $5 \mathrm{~mL} \mathrm{SM}$ was added, and the cell suspension was then centrifuged at $1150 \mathrm{rpm}$ for 5 minutes. The total viable cell count was obtained from a ViCell-XR Automated Cell Counter (Beckman Coulter, Fullerton, CA, USA). This cell culture protocol was followed for cell expansion from passage 0 to passage 2. On passage 3 , RAW 264.7 cells were plated at a concentration of $2.0 \times$ $10^{5}$ cells/well in 6 -well plates. These cell culture procedures were repeated 6 times.

2.4. Rat Stromal Bone Marrow Cells (rSBMCs). rSBMCs were harvested from the femora of 100-120 g Wistar rats. The harvested femora were soaked and washed for 10 minutes three times with $\alpha$-MEM medium (Gibco) supplemented with $10 \%$ antibiotics (as above). Both epiphyses were cut off and the bone marrow was gently flushed out from both sides with a $10 \mathrm{~mL}$ syringe (fitted with a 20 -gauge needle) filled with fully supplemented medium (FSM: $10 \%$ FBS, $80 \% \alpha$ MEM and $10 \%$ antibiotics). The volume of bone marrow suspension was adjusted to $30 \mathrm{~mL}$ with FSM and divided in two aliquots of $15 \mathrm{~mL}$ each, which were distributed in two T-75 flasks. The first medium change was done at 24 hours and then three times per week subsequently. Cells were grown for 5 to 6 days to $80-85 \%$ confluence. At each passage, and up to passage $8,1.0 \times 10^{6}$ cells were collected and fixed with formalin in a $1.5 \mathrm{~mL}$ microcentrifuge tube for flow cytometry (Beckman Coulter, Miami, FL, USA) analysis of the CD45 positive cell population (CD45, mouse anti-rat Caltag Laboratories, Burlingame, CA, USA), for investigation of the presence of hematopoietic cells. Aliquots of $2.0 \times 10^{6} \mathrm{cells} / \mathrm{cm}^{2}$ of the rSBMCs at passage 7 were seeded into 6-well plates. The passage 7 was chosen in this assay because passage 7 included only $0.36 \%$ of $\mathrm{CD} 45^{+}$cells. Stromal cells were isolated from bone marrow of two rats for quantification of $\mathrm{CD} 45^{+}$cells.

2.5. LPS Preparations. hGFs were stimulated with different types of LPS: P. gingivalis, P. intermedia, and E. coli LPS (Escherichia coli 055:B5, Sigma-Aldrich). Both LPS of P. gingivals and $P$. intermedia were isolated from colonies of these bacterial cultures. The strains used in this study were P. intermedia ATCC 25611, P. gingivalis ATCC 33277. All anaerobes were maintained on Brucella HK agar (Kyokuto, Tokyo, Japan) supplemented with $5 \%$ laked sheep blood in an atmosphere of $80 \% \mathrm{~N}_{2}, 10 \% \mathrm{CO}_{2}$, and $10 \% \mathrm{H}_{2} \mathrm{O}$ in the aerobic chamber for 48 hours 37 degrees. LPS was extracted by using an LPS extraction kit (iNtRON Biotechnology, Kyunggi-do, Korea), dissolved in $10 \mathrm{mM}$ Tris-HCl buffer, and freeze-dried.

2.6. LPS Stimulation of Cells. In separate experiments, hBMCs and hGFs were stimulated with E. coli LPS $(0 \mu \mathrm{g} / \mathrm{mL}$ or $0.1 \mu \mathrm{g} / \mathrm{mL}$ or $1 \mu \mathrm{g} / \mathrm{mL}$ ) for 24,48 , or 96 hours, and they were stimulated with $P$. gingivalis LPS or $P$. intermedia LPS $(1 \mu \mathrm{g} / \mathrm{mL})$ for 2 or 24 hours (37 degrees, $\left.5 \% \mathrm{CO}_{2}\right)$.

RAW 264.7 cells were stimulated with E. coli LPS (Escherichia coli $055: \mathrm{B} 5$, Sigma-Aldrich) $(0 \mu \mathrm{g} / \mathrm{mL}$ or $1 \mu \mathrm{g} / \mathrm{mL}$ ) for $12,24,36,48$, and 60 hours; hMO were stimulated with LPS $(0 \mu \mathrm{g} / \mathrm{mL}$ or $1 \mu \mathrm{g} / \mathrm{mL})$ for 24 hours; rSBMCs were stimulated with E. coli LPS $(0 \mu \mathrm{g} / \mathrm{mL}$ or $0.1 \mu \mathrm{g} / \mathrm{mL}$ or $1 \mu \mathrm{g} / \mathrm{mL}$ ) for $6,24,48$ and 96 hours; hBMCs and hGFs were stimulated with E. coli LPS $(0 \mu \mathrm{g} / \mathrm{mL}$ or $0.1 \mu \mathrm{g} / \mathrm{mL}$ or $1 \mu \mathrm{g} / \mathrm{mL}$ ) for 24,48 , and 96 hours. In each case, LPS was added to the culture medium when cells reached $75-80 \%$ confluence, which was approximately at day 3 for $\mathrm{mMO}$ and day 7 for rSBMCs, hGFs, and hBMCs. LPS was added into the culture medium every 24 hours. Cell culture supernatants of hBMCs and hGFs were harvested and stored at -80 degrees prior to enzyme-linked immunosorbent assay (ELISA, Thermo Fisher Scientific, Waltham, MA, USA). RNA was isolated from both LPS stimulated cells and cell, lysate after the culture medium was removed (see below).

2.7. Detection of Cytokine Expression (RT-PCR). Total cellular RNA was extracted from hBMCs, hGFs, hMO, mMO and rSBMCs. with $1 \mathrm{~mL} / 10 \mathrm{~cm}^{2}$ culture dish area of TRI Reagent (Ambion, Austin, TX, USA). cDNA templates of these cells were produced using a reverse transcriptase kit (Quanti Tect Reverse Transcription kit, Qiagen, Mississauga, ON, USA). GAPDH, a house-keeping gene, was used for all species of human, rat, and mouse. Specific primers of IL- $1 \alpha$, IL- $1 \beta$, TNF- $\alpha$, IL-6, RANK, RANKL, TRL-2, TRL4, CD14 and MD-2 were designed for human or rat, and mouse individually using an electronic gene database 
(BLAST, National Library of Medicine). The specific primers (Table 1) were added to each cDNA sample to be amplified using a Taq polymerase kit (Platinum Taq DNA polymerase, Invitrogen, Carisbad, CA, USA). Expression of cDNA was assessed by running 25 to 35 cycles at 55 degrees to 65 degrees on reverse transcriptase-polymerase chain reaction (RT-PCR) amplification. Amplified products were analyzed by $1.5 \%$ agarose gel electrophoresis and visualized with ethidium bromide (Sigma-Aldrich) staining. RT-PCR was repeated at least 3 times for each cell type.

2.8. Determination of Cytokine Secretion (ELISA). Culture supernatants from each cell type were removed and stored at -80 degrees prior to ELISA analysis. ELISA kits were used to quantify IL- $1 \alpha$, IL- $1 \beta$, TNF- $\alpha$, and IL- 6 concentration in cellfree culture supernatants according to the manufacturer's protocols. hBMCs and hGFs were extracted with a lysis buffer (Cell Signaling Technology, Beverly, MS, USA) and the protein lysates were stored in the same manner. ELISA kits were used to quantify IL- $1 \alpha$, IL- $1 \beta$, and TNF- $\alpha$ concentration in cell lysates according to the manufacturer's protocols. The absorbance at $450 \mathrm{~nm}$ was read with wavelength correction set at $550 \mathrm{~nm}$. The sensitivities of the commercial ELISA kits were $<2 \mathrm{pg} / \mathrm{mL}$ for IL- $1 \alpha,<1 \mathrm{pg} / \mathrm{mL}$ for IL- $1 \beta,<2 \mathrm{pg} / \mathrm{mL}$ for TNF- $\alpha$, and $<1 \mathrm{pg} / \mathrm{mL}$ for IL- 6 . The number of samples of cell-free culture supernatant samples, the cell lysate samples, and the times of repeated analysis of each sample are shown in Table 2 . The concentration of IL- $1 \alpha$, IL- $1 \beta$, IL- 6 , and TNF$\alpha$ was analyzed in cell-free culture supernatants and the cell lysate for hBMCs and hGFs. In hMO, we analyzed only the concentration of IL- $1 \alpha$ and IL- $1 \beta$.

2.9. TRAP (Tartrate Resistant Acid Phosphatase) Staining. mMO (RAW 264.7) were washed with PBS and fixed with $10 \%$ formalin at room temperature for 5 minutes. Then, they were washed with distilled water and incubated in michaelis veronal acetate buffer ( $\mathrm{pH}$ 5.0) containing naphtol AS-BI phosphate as substrate, pararosanilin-HCL as coupler, and tartaric acid for detection of TRAP activity, for 40 minutes at 37 degrees. After removal of the TRAP incubation buffer, cells were washed with distilled water. They were analyzed and counted in micrographs taken with a digital camera attached to the light microscope.

2.10. TRAP Assay. mMO cells in a 96-well plate were washed with PBS and add $100 \mu \mathrm{L} /$ well of the assay solution: $1 \mathrm{ml}$ of $0.1 \mathrm{M}$ pNPP (disodium p-Nitrophenylphophate hexahydrate), $1 \mathrm{ml}$ of $\times 10$ buffer $(1 \mathrm{M}$ sodium acetate and $0.1 \mathrm{M}$ sodium tartrate), $1 \mathrm{ml}$ of $0.1 \%$ Triton-X, and fill up to $10 \mathrm{ml}$ with distilled water. Incubate the plate for 10 minutes at room temperature and add $50 \mu \mathrm{L} /$ well of $0.2 \mathrm{M} \mathrm{NaOH}$ as a stop solution. Then, measure the absorbance at $405 \mathrm{~nm}$.

2.11. Bone Resorption Assay. The osteoclastic bone resorption assay was performed using the commercially available OSTEOLOGIC culture system (BioCoat Osteologic Bone Cell Culture System, BD), in which the substrate is coated with a thin layer of osteoclast resorbable calcium phosphate ceramic [33]. RAW 264.7 cells $\left(1.0 \times 10^{4}\right.$ cells/well $)$ were cultured on the OSTEOLOGIC plates for 1 day. Then, LPS $(1 \mu \mathrm{g} / \mathrm{mL}$ ), or RANKL (receptor activator of nuclear factor $\kappa \mathrm{B}$ ligand) $(200 \mathrm{ng} / \mathrm{mL})$ was added to the cell culture medium, and cells were stimulated with either LPS or RANKL for 7 days. Un-stimulated cells were used as controls. After 7 days, the cell culture medium was removed and cells were fixed with 10\% formalin. Micrographs of the OSTEOLOGIC plates were taken with SEM (Scanning electron microscopy). This cell culture procedure was repeated three times.

\section{Results}

3.1. Effects of Various LPS on Pro-Inflammatory and Osteoclastogenic Gene Expression. We investigated the effects of different types of LPS on pro-inflammatory and osteoclastogenic cytokine gene expression following exposure to LPS for 2 hours in hGF.

All three LPS types (derived from E.coli, P. gingivalis, $P$. intermedia.) showed similar upregulation of IL- $1 \beta$, IL- 6 , and RANKL gene expression (Figures 1(b), 1(c), and 1(e)). TNF$\alpha$ and RANKL expression was detected in both non-LPS and LPS conditions (Figures 1(d) and 1(f)).

\subsection{Effects of Different LPS on LPS Receptors and Their Related} Gene Expression. We next examined the effects of LPS on the TRL 2 and TRL 4 LPS receptors and their signaling cascade factors (Figure 2(a)). Without LPS, no TRL 2 or TRL 4 gene expression was observed. This was also the case for CD14 gene expression, although MD-2 was expressed with or without LPS stimulation (Figure 2(b)).

These assays illustrated that all three LPS extracts exhibited similar effects. Therefore, for convenience, we selected E. coli LPS for subsequent experiments as it is commercially available.

The examination of various LPS effect on gene expression was analyzed using hGF. However, our experimental purpose was to investigate the cellular influence on osteoclastogenesis in the surrounding tissue cells. Therefore, we also examined the effect of macrophages and bone marrow cells, which could be expected to exist around dental implant fixtures, from human, mouse, and rat.

3.3. Human Macrophages. hMO expressed IL-1 $\beta$ and TNF$\alpha$ gene in the presence or absence of LPS for 24 hours at 35 cycles of RT-PCR (Figure 3). Both IL- $1 \alpha$ and IL-6 expression was increased by LPS stimulation in human macrophages at 30 cycles of RT-PCR (Figure 3 ).

3.4. Mouse Macrophages. mMO cultures showed that the expression of IL- $1 \alpha$, IL- $1 \beta$, and IL- 6 genes was upregulated with LPS stimulation at 30 cycles of RT-PCR (Figure 4). However, gene expression of TNF- $\alpha$ was observed irrespective of LPS stimulation at all time points, except for 60 hours (Figure 4). Therefore in our experiments, TNF- $\alpha$ expression was not upregulated by LPS. The IL- $1 \alpha$ and IL6 gene expression decreased at 48 hours, while IL-1 $\beta$ gene 
TABLE 1: Specific primers for the reverse transcriptase polymerase chain reaction (RT-PCR) and the predicted sizes of the PCR products (bp).

(a) Specific primers for mouse

\begin{tabular}{lccc}
\hline Specificity & Primer & Detection & Product size (bp) \\
\hline IL-1alpha & Sense & TGCCACCAAAGAACAAAGTCG & 599 \\
& Antisense & CCCACTGAGGTAGGAAAGATGTAGC & 269 \\
IL-1beta & Sense & TCTTTGAAGTTGACGGACCCC & 288 \\
& Antisense & CCAGCAGGTTATCATCATCATCCC & 229 \\
\hline \multirow{2}{*}{ IL-6 } & Sense & ACCGTCAGCCGATTTGCTATC & 2 \\
& Antisense & TCAGAGTAAAGGGGTCAGAGTGGG & \\
\hline
\end{tabular}

(b) Specific primers for rat

\begin{tabular}{lccc}
\hline Specificity & Primer & Detection & Product size (bp) \\
\hline \multirow{2}{*}{ IL-1alpha } & Sense & AGGTTCCACGTTTCCTCCTT & 233 \\
& Antisense & GCCTCCAGGTCATCTTCAGT & 395 \\
\multirow{2}{*}{ IL-1beta } & Sense & CAACAAAAATGCCTCGTGC & 292 \\
& Antisense & AAGTCAACTATGTCCCGAC & \multirow{2}{*}{ TNF-alpha } \\
& Sense & TACTGAACTTCGGGGTGATCG & 156 \\
\hline \multirow{2}{*}{ AL-6 } & Sense & CCTTGTCCCTTGAAGAGAACC & \\
\hline
\end{tabular}

(c) Specific primers for human

\begin{tabular}{|c|c|c|c|}
\hline Specificity & Primer & Detection & Product size (bp) \\
\hline \multirow{2}{*}{ IL-1alpha } & Sense & TTCATTGGCGTTTGAGTCAG & \multirow{2}{*}{163} \\
\hline & Antisense & GGAGTGGGCCATAGCTTACA & \\
\hline \multirow{2}{*}{ IL-1beta } & Sense & GCATCCAGCTACGAATCTCC & \multirow{2}{*}{193} \\
\hline & Antisense & TCGTTATCCCATGTGTCGAA & \\
\hline \multirow{2}{*}{ TNF-alpha } & Sense & ACAAGCCTGTAGCCCATGTT & \multirow{2}{*}{265} \\
\hline & Antisense & TTGATGGCAGAGAGGAGGTT & \\
\hline \multirow{2}{*}{ IL-6 } & Sense & GCTATGAACTCCTTCTCCACAAGC & \multirow{2}{*}{264} \\
\hline & Antisense & TTCTGCCAGTGCCTCTTTGC & \\
\hline \multirow{2}{*}{ RANK } & Sense & ATGCGGTTTGCAGTTCTTCT & \multirow{2}{*}{384} \\
\hline & Antisense & CGTAGGGACCACCTCCTACA & \\
\hline \multirow{2}{*}{ RANKL } & Sense & AGAGCGCAGATGGATCCTAA & \multirow{2}{*}{180} \\
\hline & Antisense & TTCCTTTTGCACAGCTCCTT & \\
\hline \multirow{2}{*}{ TRL 2} & Sense & TTAGCAACAGTGACCTACAGAG & \multirow{2}{*}{503} \\
\hline & Antisense & CAAATCAGTATCTCGCAGTTCC & \\
\hline \multirow{2}{*}{ TRL 4} & Sense & TGGATACGTTTCCTTATAAG & \multirow{2}{*}{507} \\
\hline & Antisense & GAAATGGAGGCACCCCTTC & \\
\hline \multirow{2}{*}{$\mathrm{CD} 14$} & Sense & CAACTTCTCCGAACCTCAGC & \multirow{2}{*}{271} \\
\hline & Antisense & TAGGTCCTCGAGCGTCAGTT & \\
\hline \multirow{2}{*}{$\mathrm{MD}-2$} & Sense & GCACATTTTCTACATTCC & \multirow{2}{*}{157} \\
\hline & Antisense & CACAGTCTCTCCСТTCAG & \\
\hline
\end{tabular}

(d) Specific primers for House keeping gene

\begin{tabular}{lccc}
\hline Specificity & Primer & Detection & Product size (bp) \\
\hline \multirow{2}{*}{ GAPDH } & Sense & ACCACAGTCCATGCCATCAC & 452 \\
& Antisense & TCCACCACCCTGTTGCTGTA & \\
\hline
\end{tabular}




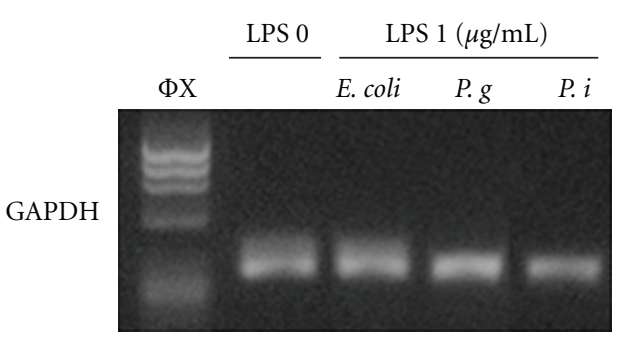

(a)

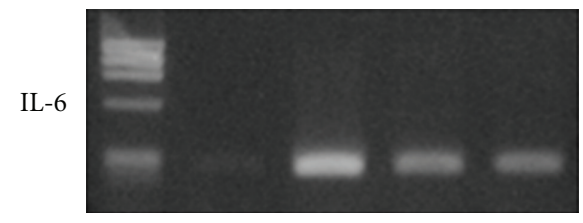

(c)

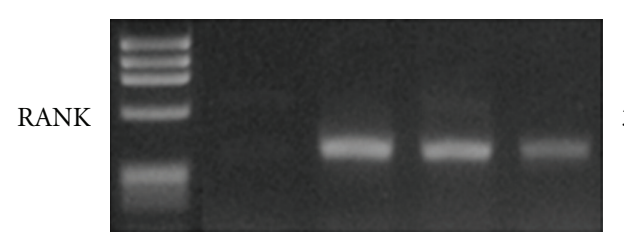

(e)

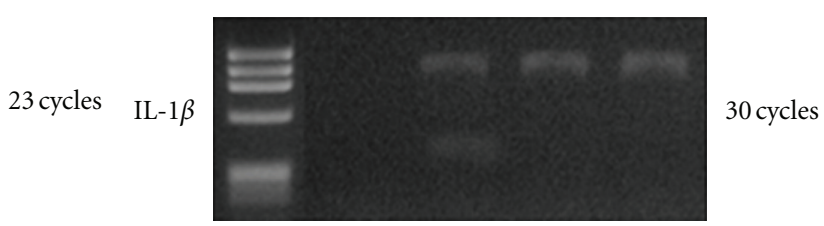

(b)

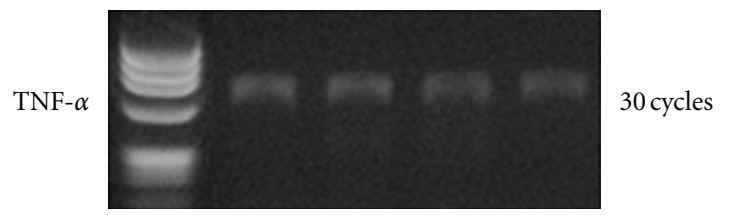

(d)

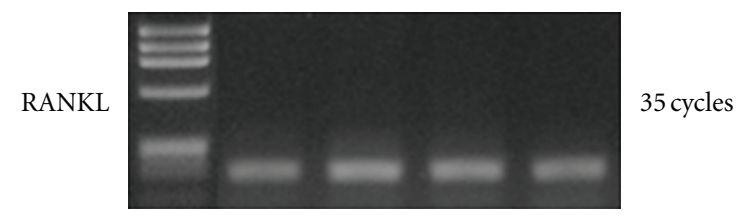

(f)

FIGURE 1: Expression of pro-inflammatory and osteoclastogenic genes with several LPS stimulation in human gingival fibroblasts. IL-1 $\beta$, IL-6, TNF- $\alpha$, RANL, RANKL, and GAPDH gene expression in hGF cultures with different types of LPS stimulation: E. coli, $P$. gingivalis, $P$. intermedia and without LPS for 2 hours. $1 \mu \mathrm{g} / \mathrm{mL}$ of LPS was used in the experiment. mRNA was isolated at 2 hours. RT-PCR was carried out at different cycles for each gene. Annealing temperature was 55 degrees for all genes.

TABLE 2: The samples for ELISA analysis were cell-free culture supernatants and protein lysate. Both the cell-free culture supernatant samples and the protein lysate samples of hBMCs and hGFs were obtained from three different donors and analyzed twice. The cell-free culture supernatant samples of hMO were obtained from one donor. The LPS without samples were analyzed twice and the LPS with samples were analyzed four times. The protein lysate samples were not prepared from hMO.

\begin{tabular}{lcccccc}
\hline The samples for ELISA & \multicolumn{2}{c}{ Human Macrophages } & \multicolumn{2}{c}{ HBMCs } & HGFs \\
\hline \multirow{3}{*}{ Cell-free culture supernatant } & LP - & LPS & LPS - & LPS + & LPS - & LPS + \\
& $n=1$ & $n=1$ & $n=3$ & $n=3$ & $n=3$ & $n=3$ \\
& Analyzed twice & Analyzed four times & Analyzed twice & Analyzed twice & Analyzed twice & Analyzed twice \\
\hline \multirow{3}{*}{ Protein lysate } & LP - & LPS & LPS - & LPS + & LPS - & LPS + \\
& $\times$ & $\times$ & $n=3$ & $n=3$ & $n=3$ & $n=3$ \\
& $\times$ & Analyzed once & Analyzed once & Analyzed once Analyzed once \\
\hline
\end{tabular}

expression was decreased at 60 hours after LPS stimulation (Figure 4).

3.5. Human Bone Marrow Cells. hBMCs showed a similar trend for gene expression of cytokines as that found with rSBMCs (Figure 5). The gene expression of IL- $1 \alpha$, IL- $1 \beta$, and IL- 6 was stimulated by the presence of LPS. However, the expression of IL- $1 \alpha$ and IL- $1 \beta$ gene was reduced at 96 hours in hBMCs culture. TNF- $\alpha$ gene expression also occurred in the presence of LPS at 24 hours and 48 hours (Figure 5). Nevertheless, the TNF- $\alpha$ expression was very weak at each LPS concentration and time point. The LPS-stimulated genes for IL- $1 \alpha$ and IL- $1 \beta$ were observed by RT-PCR at 30 cycles, and for IL-6 gene at 25 cycles.

3.6. Rat Stromal Bone Marrow Cells. LPS upregulated gene expression of IL- $1 \alpha$, IL- $1 \beta$, and IL- 6 during the rSBMCs poststimulation period (6-96 hours, Figure 6), showing the same trend of mMO cultures. The expression of TNF- $\alpha$ gene in the presence of LPS at 6 and 48 hours at 30 cycles was very weak (Figure 6). Running cycles for RT-PCR were same as hBMCs.

Although we used hGF for estimating the effect of different LPS in this study, those experiments were carried out with 2 hours LPS exposure. We also investigated the LPS effects against hGF with longer time periods, 24, 48, and 96 hours, in a subsequent experiment.

3.7. Human Gingival Fibroblasts. All genes, for IL-1 $\alpha$, IL$1 \beta$, TNF- $\alpha$, and IL- 6 , were expressed in the presence of LPS at all time points in hGF cultures. However, expression of IL-1 $\beta$ was not expressed at 96 hours in spite of increased (+5) cycles; the expression of IL- $1 \alpha$, IL- $1 \beta$, and TNF- $\alpha$ was observed at 35 cycles. Interestingly, all gene expression was 

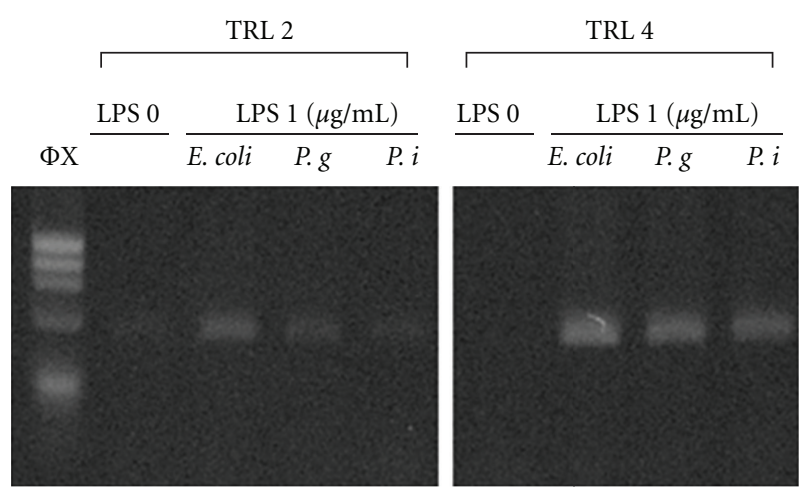

30 cycles

(a)
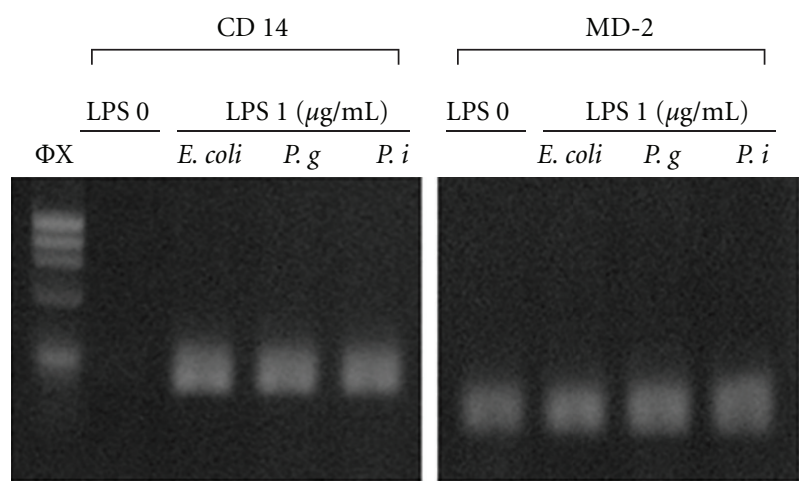

(b)

FIGURE 2: Expression of LPS receptors and their signaling factor's genes with several LPS stimulation in human fibroblasts. TRL 2, TRL 4, CD14, and MD-2 gene expression in hGF cultures with different types of LPS stimulation: E. coli, P. gingivalis, P. intermedia, and without LPS for 2 hours. $1 \mu \mathrm{g} / \mathrm{mL}$ of LPS was used in the experiment. mRNA was isolated at 2 hours. RT-PCR was carried out at different annealing temperature that TRL2 and CD14 were 57 degrees, and TRL 4 and MD-2 were 54 degrees. PCR cycle was 30 cycles for all genes.

stronger at $0.1 \mu \mathrm{g} / \mathrm{mL}$ than at $1 \mathrm{~g} / \mathrm{mL}$ LPS (Figure 7). LPSstimulated IL- $1 \alpha$ and IL- $1 \beta$ gene expression was reduced in a time-dependent manner, however, IL-6 gene expression increased especially with $1 \mu \mathrm{g} / \mathrm{mL}$ concentration of LPS (Figure 7). The expression of IL-6 gene was observed at 25 cycles.

\section{Effect of LPS on Protein Secretion}

ELISA was used to assess levels of protein secretion (IL- $1 \alpha$, IL- $1 \beta$, TNF- $\alpha$, and IL-6) in cultures of hMOs, hBMCs, and hGFs.

4.1. Human Macrophages. Significant secretion of IL- $1 \alpha$ and IL- $1 \beta$ was found in the cell-free culture supernatant after stimulation with LPS for 24 hours (Table 3(a)). IL- $1 \alpha$ and IL- $1 \beta$ concentrations were approximately 470 times and 12.5 times higher in the presence of LPS.

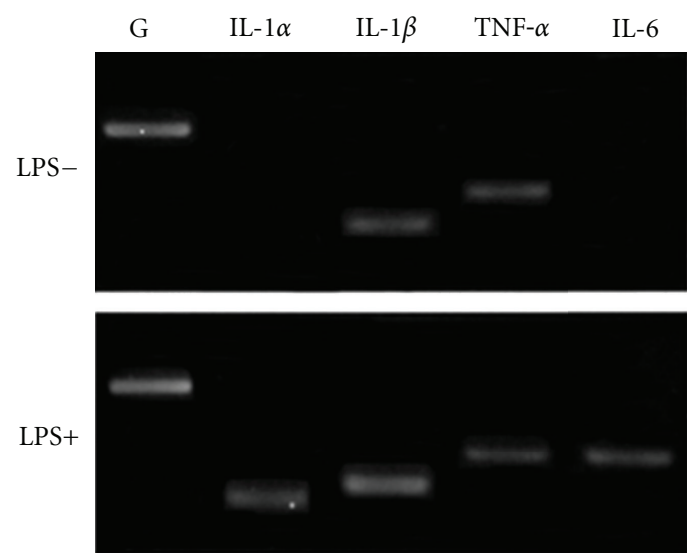

FIgURE 3: Expression of pro-inflammatory cytokine genes in human macrophages. IL- $1 \alpha$, IL- $1 \beta$, TNF- $\alpha$, IL- 6 , and GAPDH gene expression in hMO cultures with and without LPS stimulation for 24 hours. $1 \mu \mathrm{g} / \mathrm{mL}$ of LPS was used in the experiment. mRNA was isolated at 24 hours. RT-PCR was carried out at 30 cycles for all genes.

4.2. Human Bone Marrow Cells. The analysis of cell lysate by ELISA revealed that LPS-stimulated hBMCs secreted IL- $1 \alpha$ at 24 hours and IL- $1 \beta$ at 24, 48, and 96 hours (Table 3(b)) but these protein levels were very low. Secretions of TNF- $\alpha$ from protein lysate were detected both with and without LPS at all time points (Table 3(b)). However, the levels of TNF$\alpha$ secretion were also very low. Thus, the secretion of IL- $1 \alpha$, IL- $1 \beta$, and TNF- $\alpha$ was meaningless in hBMCs cultures.

To the contrary, the level of IL- 6 secretion was extremely high in the presence of LPS in hBMCs (Figure 8(a)). IL6 concentration was approximately 40000 times higher at 96 hours in the presence of LPS as maximum compared to absence of LPS. The secretions of IL- 6 from cell-free culture supernatants were detected from only with LPS at all time points (Figure 8(a)). Therefore, the secretion of IL-6 protein was induced by LPS stimulation in a time-dependent manner, but not an LPS dose-dependent manner.

4.3. Human Gingival Fibroblasts. Secretion of TNF- $\alpha$ was not specific to the presence of LPS stimulation at 24, 48, and 96 hours (Table 3(c)). The secretion of TNF- $\alpha$ was not induced by LPS stimulation in hGFs.

The levels of IL-6 protein were clearly increased with LPS in hGFs (Figure $8(\mathrm{~b})$ ). The secretions of IL-6 were detected from cell-free culture supernatants at all time points: 24,48 and 96 hours. Secretion of IL- 6 by hGFs in the presence of LPS stimulation was found to be time- and dose-dependent hGFs (Figure 8(b)).

\section{Effect of LPS on the Differentiation of Mouse Macrophages into Osteoclasts}

\subsection{Observation of Differentiation of Osteoclasts}

5.1.1. TRAP Assay. mMO (RAW 264.7 cells) were cultured in medium with $300 \mathrm{ng} / \mathrm{mL}$ GST-RANKL for 3 days demonstrated the highest TRAP positive reaction compared to 


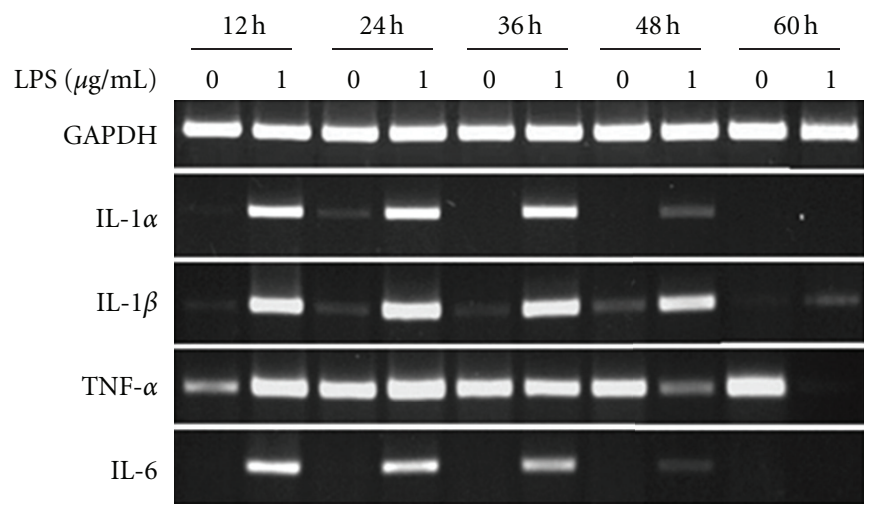

FIGURE 4: Expression of pro-inflammatory cytokine genes in mouse macrophages (RAW 264.7). Gene expression of IL- $1 \alpha$, IL-1 $\beta$, TNF- $\alpha$, IL-6, and GAPDH in mMO cultures in the absence $(0 \mu \mathrm{g} / \mathrm{mL})$ and presence $(1 \mu \mathrm{g} / \mathrm{mL})$ of LPS. RNA was isolated at $12,24,36,48$, and 60 hours. RT-PCR was carried out at 30 cycles for all genes in this experiment.

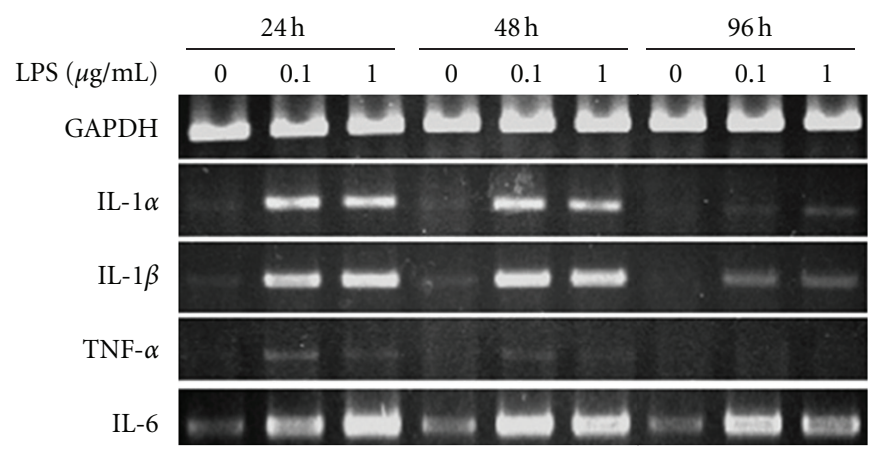

FIGURE 5: Expression of pro-inflammatory cytokine genes in human bone marrow cells. IL-1 $\alpha$, IL- $1 \beta$, TNF- $\alpha$, IL-6, and GAPDH gene expression in hBMCs cultures with or without LPS stimulation. LPS concentrations were $0 \mu \mathrm{g} / \mathrm{mL}, 0.1 \mu \mathrm{g} / \mathrm{mL}$ or $1 \mu \mathrm{g} / \mathrm{mL}$. RNA was isolated at 24,48 , and 96 hours. RT-PCR was carried out at 30 cycles for GAPDH, IL- $1 \alpha$, IL-1 $\beta$, and TNF- $\alpha$, and 25 cycles for IL-6.

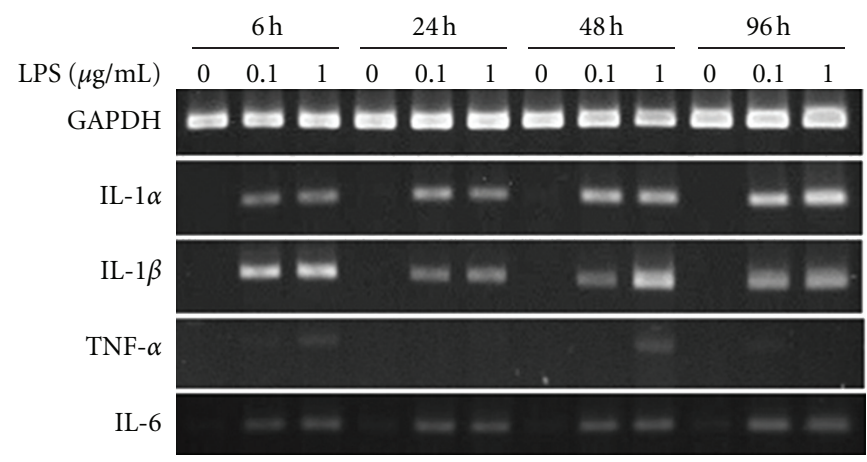

FIGURE 6: Expression of pro-inflammatory cytokine genes in rat stromal bone marrow cells. Gene expression for IL- $1 \alpha$, IL- $1 \beta$, TNF- $\alpha$, IL-6 and GAPDH in rSBMCs cultures in the presence and absence of LPS. The LPS concentrations used were $0.1 \mu \mathrm{g} / \mathrm{mL}$ and $1 \mu \mathrm{g} / \mathrm{mL}$. RNA was isolated at 6, 24, 48 and 96 hours. RT-PCR was carried out at 30 cycles for GAPDH, IL-1 $\alpha$, IL-1 $\beta$, and TNF- $\alpha$, and 25 cycles for IL-6.

negative controls, without RANKL, and LPS stimulated mMO (Figure 9). The various LPS did not show different TRAP positive ability. The various LPS did not show different TRAP positive ability mostly.

5.1.2. TRAP Staining. $\mathrm{mMO}$ were cultured in medium containing $1 \mu \mathrm{g} / \mathrm{mL}$ LPS for 5 to 7 days and observed under phase contrast for the presence of multinucleated cells (MNCs) (Figure 10(b)). The MNCs were enlarged the size, but the amount of MNCs was decreased at day 7. mMO did not show morphological changes in the absence of LPS (Figure 10(a)).

Osteoclast formation was examined by TRAP staining, which is a selectable staining to identify osteoclasts and activated macrophages. TRAP-positive mononuclear cells and MNCs were observed in mMO cultures in the presence of LPS (Figure 10(e)) and in the presence of RANKL (Figure $10(\mathrm{~h})$ ). mMO cultures without the addition of LPS or RANKL were used as negative control and did not show positive reaction to TRAP staining (Figure $10(\mathrm{c})$ ). $\mathrm{mMO}$ 


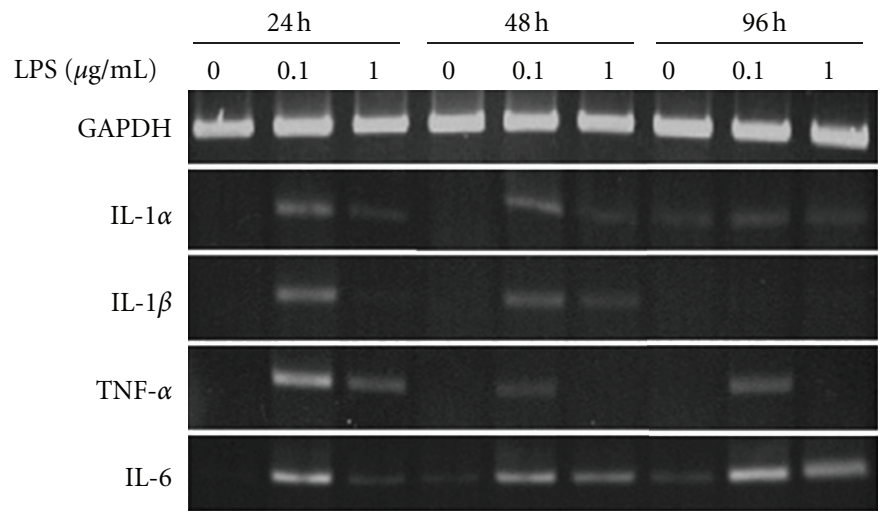

FIGURE 7: Expression of pro-inflammatory cytokine genes in human gingival fibroblasts. Gene expression for IL- $1 \alpha$, IL-1 $\beta$, TNF- $\alpha$, IL-6, and GAPDH genes in hGF cultures with and without LPS stimulation. LPS concentrations were $0 \mu \mathrm{g} / \mathrm{mL}, 0.1 \mu \mathrm{g} / \mathrm{mL}$ or $1 \mu \mathrm{g} / \mathrm{mL}$. RNA was isolated at 24, 48, and 96 hours. RT-PCR was carried out at 30 cycles for GAPDH, 35 cycles for IL- $1 \alpha$, IL- $1 \beta$, and TNF- $\alpha$, and 25 cycles for IL-6.

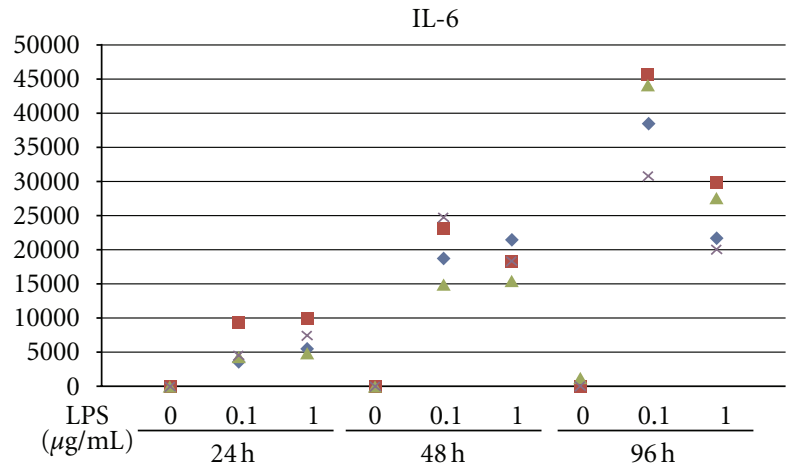

(a)

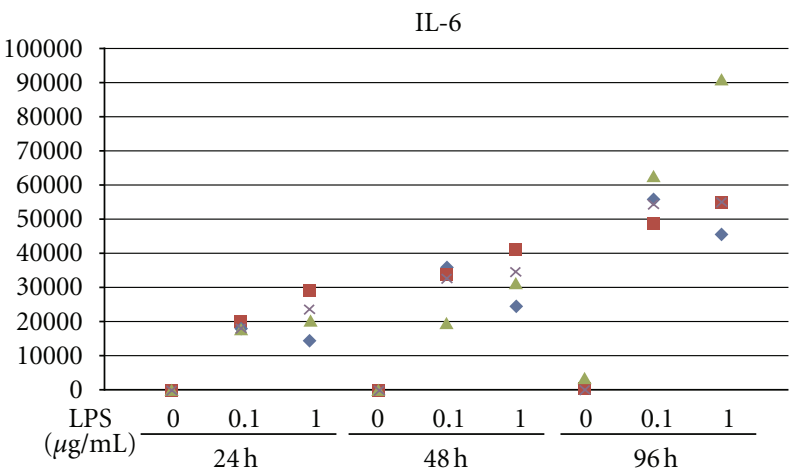

(b)

FIGURE 8: (a) Secretion of IL-6 protein in human bone marrow cells IL-6 secretion in hBMCs cultures with and without LPS stimulation for 24,48 , and 96 hours. LPS concentrations were $0 \mu \mathrm{g} / \mathrm{mL}, 0.1 \mu \mathrm{g} / \mathrm{mL}$ or $1 \mu \mathrm{g} / \mathrm{mL}$. The amount of IL- 6 in cell-free culture supernatants was analyzed by ELISA. (b) secretion of IL-6 protein in human gingival fibroblasts Secretion of IL-6 in hGFs with or without LPS stimulation for 24,48 , and 96 hours. LPS concentrations were $0 \mu \mathrm{g} / \mathrm{mL}, 0.1 \mu \mathrm{g} / \mathrm{mL}$ or $1 \mu \mathrm{g} / \mathrm{mL}$. The amount of IL-6 in cell-free culture supernatants was analyzed by ELISA.

cultures stimulated with RANKL were used as a positive control (Figure 10(h)).

5.2. Observation of Activation of Osteoclasts. Pit forming activity was analyzed using the commercially available BioCoat Osteologic Bone Cell Culture System (Osteologic), which consists of quartz plates with a thin film surface coating of calcium phosphate $(\mathrm{CaP})$. Pit formation on the CaP substrates was observed in mouse macrophage cultures in the presence of LPS (Figure 10(f)) and RANKL (Figure $10(\mathrm{~g})$ ). Control cultures did not show any pit formation (Figure 10(d)).

\section{Discussion}

Although gingival and periodontal pathologies are known to cause the upregulation and secretion of pro-inflammatory cytokines, [34-36] our studies were aimed at elucidating a mechanism whereby dental implants, placed in healthy tissue, and could cause the genesis of osteoclasts that would be the effectors of peri-implant crestal bone loss. Since the latter is a local, not systemic phenomenon, there is a need to understand the local causative mechanisms. Thus, we hypothesized that bacterial products, originating from bacteria colonizing implant/abutment connections, could cause the upregulation of pro-inflammatory cytokines in the cells of healthy peri-implant tissues that would, in turn, stimulate the recruitment of resorptively active osteoclasts. Indeed, our results show that E. Coli LPS, as a model bacterial endotoxin, can selectively stimulate the upregulation of pro-inflammatory cytokines in healthy candidate resident cells, which can cause the genesis of osteoclasts that are resorptively active.

Despite differences in implant/abutment designs, implant/abutment connections will invariably form a microgap, that under function (cyclic opening/closing), will allow passage of organic fluids containing bacteria and endotoxin from and to the implant cavities [7]. Furthermore, the bacterial colonization of the internal cavities of two piece dental implants has been repeatedly demonstrated through both microscopical observations and in vitro studies [3-5]. 
TABLE 3: ELISA results for hMO (a), hBMCs (b) and hGFs (c). For hMO, protein levels were assessed from the cell-free culture supernatants. $\mathrm{hBMC}$ and hGF protein levels were quantified from the cell lysate.

(a) Secretion of IL- $1 \alpha$ and IL- $1 \beta$ by human macrophages after LPS stimulation

\begin{tabular}{lcccc}
\hline & \multicolumn{3}{c}{ IL- $\alpha$} & IL- $1 \beta$ \\
Stimulation period & LPS 0 & LPS $1 \mu \mathrm{g} / \mathrm{mL}$ & LPS 0 & LPS $1 \mu \mathrm{g} / \mathrm{mL}$ \\
\hline $24 \mathrm{hrs}$ & $0 \mathrm{pg} / \mathrm{mL}$ & $470.80 \pm 79.69 \mathrm{pg} / \mathrm{mL}$ & $32 \mathrm{pg} / \mathrm{mL}$ & $400 \mathrm{pg} / \mathrm{mL}$ \\
\hline
\end{tabular}

(b) Secretion of IL- $1 \alpha$, IL- $1 \beta$, and TNF-by human bone marrow cells after LPS stimulation

\begin{tabular}{|c|c|c|c|c|c|c|c|c|c|}
\hline \multirow[b]{3}{*}{ Stimulation period } & \multirow{2}{*}{\multicolumn{3}{|c|}{$\begin{array}{l}\text { IL- } 1 \alpha(\mathrm{pg} / \mathrm{mL}) \\
\text { LPS }(\mu \mathrm{g} / \mathrm{mL})\end{array}$}} & \multirow{2}{*}{\multicolumn{3}{|c|}{$\begin{array}{l}\mathrm{IL}-1 \beta(\mathrm{pg} / \mathrm{mL}) \\
\text { LPS }(\mu \mathrm{g} / \mathrm{mL})\end{array}$}} & \multirow{2}{*}{\multicolumn{3}{|c|}{$\begin{array}{c}\text { TNF- } \alpha(\mathrm{pg} / \mathrm{mL}) \\
\text { LPS }(\mu \mathrm{g} / \mathrm{mL})\end{array}$}} \\
\hline & & & & & & & & & \\
\hline & 0 & 0.1 & 1 & 0 & 0.1 & 1 & 0 & 0.1 & 1 \\
\hline $24 \mathrm{hrs}$ & 0 & $5.49 \pm 1.21$ & $5.11 \pm 2.03$ & 0 & $9.17 \pm 4.57$ & $16.15 \pm 1.78$ & $19.32 \pm 10.03$ & $52.95 \pm 5.26$ & $54.55 \pm 3.25$ \\
\hline $48 \mathrm{hrs}$ & 0 & $0.34 \pm 0.46$ & 0 & 0 & 0 & $15.59 \pm 1.05$ & $22.27 \pm 2.12$ & $51.48 \pm 2.33$ & $40.00 \pm 4.82$ \\
\hline $96 \mathrm{hrs}$ & 0 & 0 & 0 & 0 & 0 & 0 & $14.89 \pm 2.44$ & $42.39 \pm 8.85$ & $40.11 \pm 11.06$ \\
\hline
\end{tabular}

(c) Secretion of IL- $1 \alpha$, IL-1 $\beta$, and TNF-by human gingival fibroblasts after LPS stimulation

\begin{tabular}{|c|c|c|c|c|c|c|c|c|c|}
\hline \multirow[b]{3}{*}{ Stimulation period } & \multirow{2}{*}{\multicolumn{3}{|c|}{$\begin{array}{l}\mathrm{IL}-1 \alpha(\mathrm{pg} / \mathrm{mL}) \\
\mathrm{LPS}(\mu \mathrm{g} / \mathrm{mL})\end{array}$}} & \multirow{2}{*}{\multicolumn{3}{|c|}{$\begin{array}{l}\mathrm{IL}-1 \beta(\mathrm{pg} / \mathrm{mL}) \\
\mathrm{LPS}(\mu \mathrm{g} / \mathrm{mL})\end{array}$}} & \multirow{2}{*}{\multicolumn{3}{|c|}{$\begin{array}{c}\text { TNF- } \alpha(\mathrm{pg} / \mathrm{mL}) \\
\text { LPS }(\mu \mathrm{g} / \mathrm{mL})\end{array}$}} \\
\hline & & & & & & & & & \\
\hline & 0 & 0.1 & 1 & 0 & 0.1 & 1 & 0 & 0.1 & 1 \\
\hline $24 \mathrm{hrs}$ & 0 & 0 & 0 & 0 & 0 & 0 & $23.30 \pm 3.72$ & $28.30 \pm 1.14$ & $26.93 \pm 2.18$ \\
\hline $48 \mathrm{hrs}$ & 0 & 0 & 0 & 0 & 0 & 0 & $22.27 \pm 2.05$ & $17.84 \pm 8.17$ & $21.36 \pm 3.20$ \\
\hline $96 \mathrm{hrs}$ & 0 & 0 & 0 & 0 & 0 & 0 & $20.00 \pm 4.16$ & $19.31 \pm 6.89$ & $22.84 \pm 1.76$ \\
\hline
\end{tabular}

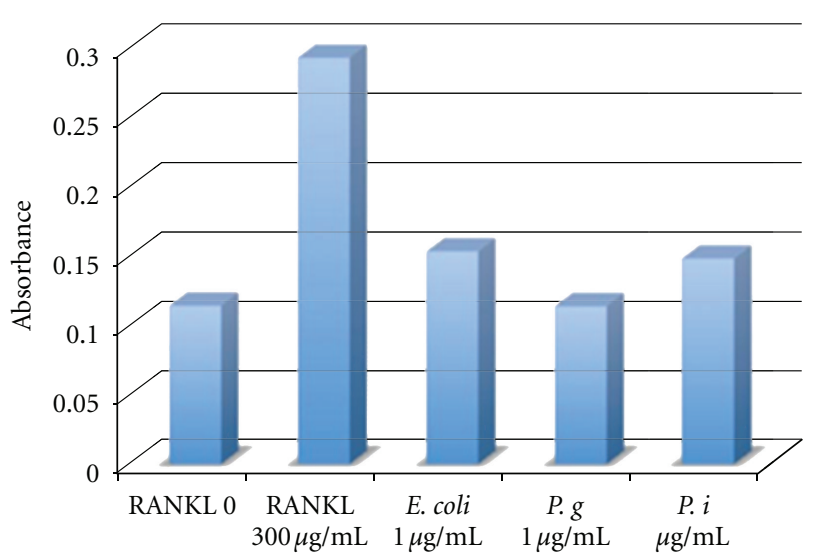

FIGURE 9: TRAP positive reactions were showed as level of absorbance in each group. The data were calculated by triplicate samples in each group. One day after mMO cells were seeded into 96 wells they were stimulated with $E$. coli, $P$. gingivalis, $P$. intermedia LPS for 3 days. $1 \mu \mathrm{g} / \mathrm{mL}$ of LPS was added into the cell culture medium individually. As positive control, we used $300 \mathrm{ng} / \mathrm{mL}$ GSTRANKL which was treated the same way with LPS groups. Negative control was not including RANKL and LPS.

In fact, it is likely that these cavities provide anaerobic chambers for pathogens that could induce an immune response in the host [9]. The intensity of such response would depend on: the immunologic profile of each individual (as is known to be the case in periodontal disease [37]); the amount and types of periodontal pathogens present in the mouth; possibly, the position (in relation to the bone crest) of the implant/abutment interface [11, 13]. Indeed, there seems to be a delicate balance between cytokines that trigger immunological response (pro-inflammatory) and those that will modulate the immunological response [38]. Interestingly, clinical studies of implant/abutment selflocking connections $[39,40]$, which are more stable and reduce fluid percolation (with respect to the less stable flat-to-flat nonself-locking components) [7], have shown a reduction in the overall loss of crestal bone.

Our results show that LPS upregulated IL- $1 \alpha$ and IL- 6 gene expression in all the examined cells types; while IL- $\beta$, and TNF- $\alpha$ were only upregulated in cultures of hBMCs, and hGFs. On the contrary, analysis of protein secretion showed very low or undetectable levels IL- $1 \alpha$, IL- $1 \beta$ and TNF- $\alpha$ in cultures of hM, hBMCs and hGFs. However, there was a clear increase in IL-6 secretion, with LPS treatment, for both hBMCs and hGFs, a finding that corresponds to previous reports $[41,42]$. Indeed, IL-6 has been shown to stimulate osteoclast activity through enhancement of the expression of RANKL with soluble IL-6 receptors (sIL-6R) in both calvarial bones [43] and osteoblasts [44], an effect reliant on the synergistic effect of IL-6 and sIL-6R [45]. Furthermore, IL-6 can stimulate osteoclast-like formation in long-term human bone marrow cultures by inducing IL- $1 \beta$ release [46]. Thus, IL-6 might be responsible for osteoclast differentiation and activation through enhancement of RANKL expression [4345].

IL- 6 has also been implicated to have a role on the pathogenesis of periodontitis. Gingival tissues obtained from diseased periodontal sites contain higher levels of IL-6 as compared to healthy sites [47] and crevicular fluid from periodontally diseased sites contain more IL- 6 than healthy sites [48]. While IL- $\beta$, IL-10, IL-12, IL-8, IL-6, and TNF- $\alpha$ have all been found to be present in peri-implant crevicular fluid, recorded levels tended to be higher than those observed around teeth, [41] and IL- 6 expression is stimulated by IL- $1 \alpha$ 


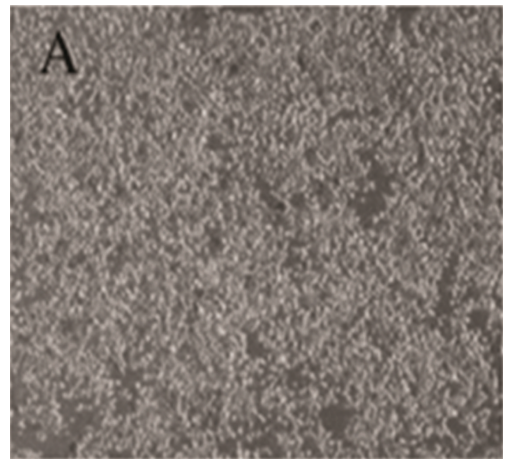

(a)

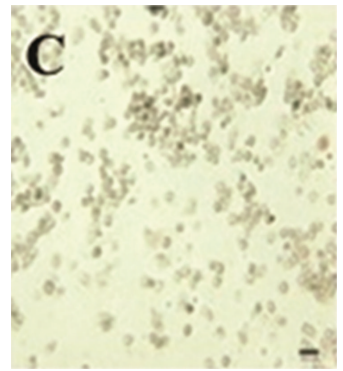

(c)

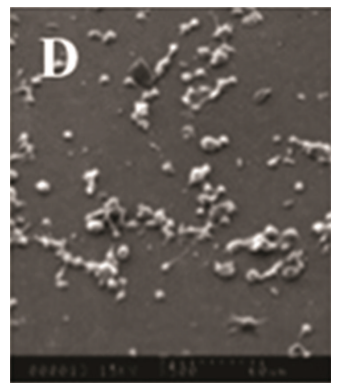

(d)

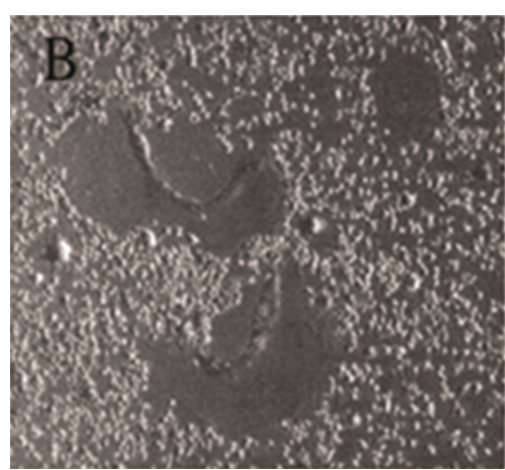

(b)

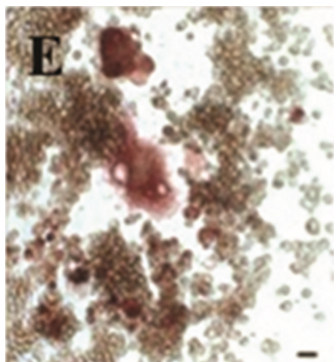

(e)

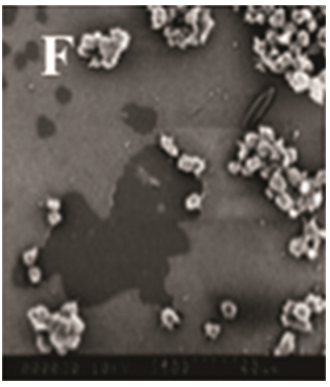

(f)

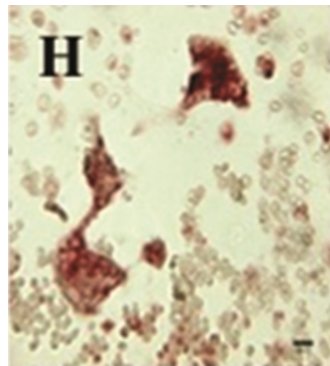

(h)

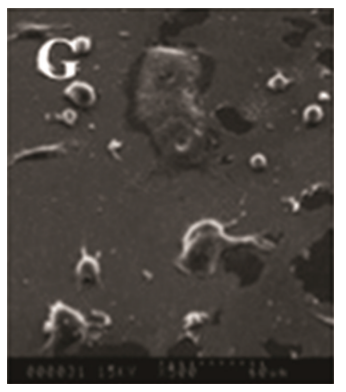

(g)

Figure 10: (a) and (b) Cell morphology of mouse macrophages in the presence of LPS Cells images were taken by phase contrast microscope (original magnification, $\times 10$ ). mMO (RAW 264.7) were cultured for 7days in the absence of LPS (a) and in the presence of $1 \mu \mathrm{g} / \mathrm{mL}$ LPS (b). (c) to (g) Osteoclast-like cells in RAW264.7 cultures induced by LPS and RANKL mMO (RAW 264.7) were incubated with $1 \mu \mathrm{g} / \mathrm{mL}$ of LPS or $200 \mathrm{ng} / \mathrm{mL}$ of RANKL for 7 days. TRAP staining images were taken by phase contrast microscope (c, e and h). Pit formation activity of osteoclasts was observed by SEM (d, f and g). (c and d) mMO seeded on CaP substrate (control), (e and f) treated with LPS and (h and g) treated with RANKL.

and TNF- $\alpha$ in hGFs [42]. Osteoblasts have also been shown to produce IL-6 in response to local bone-resorbing agents [49]. Thus, it is likely that IL-6, in cooperation with other cytokines, plays a role in the bone [36] destruction and tissue damage. In fact, increases in inflammatory cytokines are associated with bone loss and progressive failure of dental implants $[50,51]$. Since cytokines are small molecules of short life span and short acting distance-which can produce responses in very small concentrations and in a paracrine fashion-[52] this may explain why the recent introduction of platform switching in implant design $[53,54]$ contains the pro-inflammatory cytokine production to the area between the abutment and platform; thereby shielding the surrounding bone from their deleterious effects.

In comparison to the specific expression and abundant secretion of IL- 6 by hBMCs and hGFs, it is noteworthy that low amounts of IL- $1 \alpha$, IL- $1 \beta$, and TNF- $\alpha$ were also produced and secreted. The IL- $1 \alpha$ and IL- $1 \beta$ have been shown to enhance RANKL expression in both osteoblasts and stromal cells $[44,45]$, while IL- $1 \alpha$ promotes the survival of osteoclasts through NF-kB activation which results in induction of osteoclast activation [44]. These findings suggest that IL$1 \alpha$ induces differentiation and activation of multinucleate osteoclasts [55]. TNF- $\alpha$ stimulates the differentiation and survival of osteoclasts, but not the function of osteoclasts [56]. Thus, the differentiation and activation of osteoclasts could be stimulated by LPS through IL- $1 \alpha$, IL- $1 \beta$, and TNF$\alpha$. Our results show that LPS activated macrophages can form resorptively active osteoclast-like TRAP positive cells and suggest that LPS may have a direct action on resident macrophages in addition to its known ability to act indirectly on preosteoclasts [23]. 


\section{Conclusion}

Taken together, our results support the hypothesis that bacterial endotoxins may upregulate pro-inflammatory genes in a number of resident cells found in the healthy periimplant compartment, and, that the local synergistic action of cytokines secreted by such cells result in the genesis of resorptively active osteoclasts.

\section{Acknowledgments}

The authors acknowledge funding from Canadian Institutes of Health Research (CIHR) for an SME/IP PDF Fellowship [YU], the Ontario Research and Development Challenge Fund (ORDCF), and an unrestricted grant-in-aid from Biomet $3 \mathrm{i}$ (JED).

\section{References}

[1] R. Adell, U. Lekholm, B. Rockler, and P. I. Brånemark, “A 15year study of osseointegrated implants in the treatment of the edentulous jaw," International Journal of Oral Surgery, vol. 10, no. 6, pp. 387-416, 1981.

[2] J. F. Cox and G. A. Zarb, "The longitudinal clinical efficacy of osseointegrated dental implants: a 3-year report," The International Journal of Oral \& Maxillofacial Implants, vol. 2, no. 2, pp. 91-100, 1987.

[3] J. S. Guindy, C. E. Besimo, R. Besimo, H. Schiel, and J. Meyer, "Bacterial leakage into and from prefabricated screw-retained implant-borne crowns in vitro," Journal of Oral Rehabilitation, vol. 25, no. 6, pp. 403-408, 1998.

[4] S. Dibart, M. Warbington, F. S. Ming, and Z. Skobe, "In vitro evaluation of the implant-abutment bacterial seal: the locking taper system," International Journal of Oral and Maxillofacial Implants, vol. 20, no. 5, pp. 732-737, 2005.

[5] M. Quirynen, C. M. Bollen, H. Eyssen, and D. van Steenberghe, "Microbial penetration along the implant components of the Brånemark system. An in vitro study," Clinical Oral Implants Research, vol. 5, no. 4, pp. 239-244, 1994.

[6] H. Zipprich, P. Weigl, H. C. Lauer, and B. Lange, "Micromovements at the implant-abutment interface: measurements, causes, and consequences," Implantologie, vol. 15, pp. 31-45, 2007.

[7] I. Ericsson, L. G. Persson, T. Berglundh, C. P. Marinello, J. Lindhe, and B. Klinge, "Different types of inflammatory reactions in peri-implant soft tissues," Journal of Clinical Periodontology, vol. 22, no. 3, pp. 255-261, 1995.

[8] T. Berglundh and J. Lindhe, "Dimension of the periimplant mucosa biological width revisited," Journal of Clinical Periodontology, vol. 23, no. 10, pp. 971-973, 1996.

[9] N. Broggini, L. M. McManus, J. S. Hermann et al., "Persistent acute inflammation at the implant-abutment interface," Journal of Dental Research, vol. 82, no. 3, pp. 232-237, 2003.

[10] N. Broggini, L. M. McManus, J. S. Hermann et al., "Periimplant inflammation defined by the implant-abutment interface," Journal of Dental Research, vol. 85, no. 5, pp. 473-478, 2006.

[11] J. S. Hermann, D. Buser, R. K. Schenk, J. D. Schoolfield, and D. L. Cochran, "Biologic Width around one- and two-piece titanium implants-a histometric evaluation of unloaded nonsubmerged and submerged implants in the canine mandible,"
Clinical Oral Implants Research, vol. 12, no. 6, pp. 559-571, 2001.

[12] J. S. Hermann, J. D. Schoolfied, R. K. Schenk, D. Buser, and D. L. Cochran, "Influence of the size of the microgap on crestal bone changes around titanium implants. A histometric evaluation of unloaded non-submerged implants in the canine mandible," Journal of Periodontology, vol. 72, no. 10, pp. 13721383, 2001.

[13] F. F. Todescan, F. E. Pustiglioni, A. V. Imbronito, T. Albrektsson, and M. Gioso, "Influence of the microgap in the periimplant hard and soft tissues: a histomorphometric study in dogs," International Journal of Oral and Maxillofacial Implants, vol. 17, no. 4, pp. 467-472, 2002.

[14] A. Piattelli, G. Vrespa, G. Petrone, G. Iezzi, S. Annibali, and A. Scarano, "Role of the microgap between implant and abutment: a retrospective histologic evaluation in monkeys," Journal of Periodontology, vol. 74, no. 3, pp. 346-352, 2003.

[15] D. Buser and T. von Arx, "Surgical procedures in partially edentulous patients with ITI implants," Clinical Oral Implants Research, vol. 11, supplement 1, pp. 83-100, 2000.

[16] A. E. F. Pontes, F. S. Ribeiro, V. C. da Silvas et al., "Clinical and radiographic changes around dental implants inserted in different levels in relation to the crestal bone, under different restoration protocols, in the dog model," Journal of Periodontology, vol. 79, no. 3, pp. 486-494, 2008.

[17] G. N. King, J. S. Hermann, J. D. Schoofield, D. Busen, and D. L. Cochran, "Influence of the size of the microgap on crestal bone levels in non-submerged dental implants: a radiographic study in the canine mandible," Journal of Periodontology, vol. 73, no. 10, pp. 1111-1117, 2002.

[18] G. A. Hartman and D. L. Cochran, "Initial implant position determines the magnitude of crestal bone remodeling," Journal of Periodontology, vol. 75, no. 4, pp. 572-577, 2004.

[19] P. I. Brånemark, R. Adell, U. Breine, B. O. Hansson, J. Lindström, and A. Ohlsson, "Intra-osseous anchorage of dental prostheses. I. Experimental studies," Scandinavian Journal of Plastic and Reconstructive Surgery, vol. 3, no. 2, pp. 81-100, 1969.

[20] I. Ericsson, K. Nilner, B. Klinge, and P. O. Glantz, "Radiographical and histological characteristics of submerged and nonsubmerged titanium implants: an experimental study in the Labrador dog," Clinical Oral Implants Research, vol. 7, no. 1, pp. 20-26, 1996.

[21] J. S. Hermann, D. L. Cochran, P. V. Nummikoski, and D. Buser, "Crestal bone changes around titanium implants. A radiographic evaluation of unloaded nonsubmerged and submerged implants in the canine mandible," Journal of Periodontology, vol. 68, no. 11, pp. 1117-1130, 1997.

[22] N. Udagawa, N. Takahashi, T. Akatsu et al., "Origin of osteoclasts: mature monocytes and macrophages are capable of differentiating into osteoclasts under a suitable microenvironment prepared by bone marrow-derived stromal cells," Proceedings of the National Academy of Sciences of the United States of America, vol. 87, no. 18, pp. 7260-7264, 1990.

[23] S. Amano, K. Kawakami, H. Iwahashi, S. Kitano, and S. Hanazawa, "Functional role of endogenous CD14 in lipopolysaccharide-stimulated bone resorption," Journal of Cellular Physiology, vol. 173, pp. 301-309, 1997.

[24] K. Suda, J. Woo, M. Takami et al., "Lipopolysaccharide supports survival and fusion of preosteoclasts independent of TNF- $\alpha$, IL-1, and RANKL," Journal of Cellular Physiology, vol. 190, no. 1, pp. 101-108, 2002. 
[25] S. Yang, N. Takahashi, T. Yamashita et al., "Muramyl dipeptide enhances osteoclast formation induced by lipopolysaccharide, IL- $1 \alpha$, and TNF- $\alpha$ through nucleotide-binding oligomerization domain 2-mediated signaling in osteoblasts," Journal of Immunology, vol. 175, no. 3, pp. 1956-1964, 2005.

[26] K. Suda, N. Udagawa, N. Sato et al., "Suppression of osteoprotegerin expression by prostaglandin E2 is crucially involved in lipopolysaccharide-induced osteoclast formation," Journal of Immunology, vol. 172, no. 4, pp. 2504-2510, 2004.

[27] L. C. Hofbauer, D. L. Lacey, C. R. Dunstan, T. C. Spelsberg, B. L. Riggs, and S. Khosla, "Interleukin- $1 \beta$ and tumor necrosis factor- $\alpha$, but not interleukin-6, stimulate osteoprotegerin ligand gene expression in human osteoblastic cells," Bone, vol. 25, no. 3, pp. 255-259, 1999.

[28] M. Tesmer, S. Wallet, T. Koutouzis, and T. Lundgren, "Bacterial colonization of the dental implant fixture-abutment interface: an in vitro study," Journal of Periodontology, vol. 80, no. 12, pp. 1991-1997, 2009.

[29] T. Koutouzis, S. Wallet, N. Calderon, and T. Lundgren, "Bacterial colonization of the implant-abutment interface using an in vitro dynamic loading model," Journal of Periodontology, vol. 82, pp. 613-618, 2011.

[30] M. Gross, I. Abramovich, and E. I. Weiss, "Microleakage at the abutment-implant interface of osseointegrated implants: a comparative study," International Journal of Oral and Maxillofacial Implants, vol. 14, pp. 94-100, 1999.

[31] A. R. El-Awady, R. L. W. Messer, A. Y. Gamal, M. M. Sharawy, K. H. Wenger, and C. A. Lapp, "Periodontal ligament fibroblasts sustain destructive immune modulators of chronic periodontitis," Journal of Periodontology, vol. 81, no. 9, pp. 1324-1335, 2010.

[32] D. T. Graves, J. Kang, O. Andriankaja, K. Wada, and C. Rossa, "Animal models to study host-bacteria interaction involved in periodontitis," Frontiers of Oral Biology, vol. 15, pp. 117-132, 2012.

[33] J. E. Davies, G. Shapiro, and B. F. Lowenberg, "Osteoclastic resorption of calcium-phosphate ceramic thin-films," Cells and Materials, vol. 3, pp. 245-256, 1993.

[34] L. T. Hou, C. M. Liu, B. Y. Liu, S. J. Lin, C. S. Liao, and E. F. Rossomando, "Interleukin-1beta, clinical parameters and matched cellular-histopathologic changes of biopsied gingival tissue from periodontitis patients," Journal of Periodontal Research, vol. 38, pp. 247-254, 2003.

[35] M. P. Masada, R. Pearson, J. S. Kenney, S. W. Lee, R. C. Page, and A. C. Allison, "Measurement of interleukin- $1 \alpha$ and $-1 \beta$ in gingival crevicular fluid: implications for the pathogenesis of periodontal disease," Journal of Periodontal Research, vol. 25, no. 3, pp. 156-163, 1990.

[36] E. F. Rossomando, J. E. Kennedy, and J. Hadjimichael, "Tumour necrosis factor alpha in gingival crevicular fluid as a possible indicator of periodontal disease in humans," Archives of Oral Biology, vol. 35, no. 6, pp. 431-434, 1990.

[37] R. J. Genco and J. Slots, "Host responses in periodontal diseases," Journal of Dental Research, vol. 63, no. 3, pp. 441-451, 1984.

[38] S. H. Wiebe, M. Hafezi, H. S. Sandhu, S. M. Sims, and S. J. Dixon, "Osteoclast activation in inflammatory periodontal diseases," Oral Diseases, vol. 2, no. 2, pp. 167-180, 1996.

[39] J. Wennström, J. Zurdo, S. Karlsson, A. Ekestubbe, K. Gröndahl, and J. Lindhe, "Bone level change at implantsupported fixed partial dentures with and without cantilever extension after 5 years in function," Journal of Clinical Periodontology, vol. 31, no. 12, pp. 1077-1083, 2004.
[40] K. Döring, E. Eisenmann, and M. Stiller, "Functional and esthetic considerations for single-tooth Ankylos implantcrowns: 8 years of clinical performance," Journal of Oral Implantology, vol. 30, no. 3, pp. 198-209, 2004.

[41] N. M. Novotny, T. A. Markel, P. R. Crisostomo, and D. R. Meldrum, "Differential IL-6 and VEGF secretion in adult and neonatal mesenchymal stem cells: role of $\mathrm{NF} \kappa \mathrm{B}$," Cytokine, vol. 43, no. 2, pp. 215-219, 2008.

[42] L. W. Kent, F. Rahemtulla, R. D. Hockett, R. C. Gilleland, and S. M. Michalek, "Effect of lipopolysaccharide and inflammatory cytokines on interleukin- 6 production by healthy human gingival fibroblasts," Infection and Immunity, vol. 66, no. 2, pp. 608-614, 1998.

[43] P. Palmqvist, E. Persson, H. H. Conaway, and U. H. Lerner, "IL-6, leukemia inhibitory factor, and oncostatin M stimulate bone resorption and regulate the expression of receptor activator of NF- $\kappa \mathrm{B}$ ligand, osteoprotegerin, and receptor activator of NF- $\kappa$ B in mouse calvariae," Journal of Immunology, vol. 169, no. 6, pp. 3353-3362, 2002.

[44] N. Udagawa, N. Takahashi, T. Katagiri et al., "Interleukin (IL)-6 induction of osteoclast differentiation depends on IL-6 receptors expressed on osteoblastic cells but not on osteoclast progenitors," Journal of Experimental Medicine, vol. 182, no. 5, pp. 1461-1468, 1995.

[45] T. Tamura, N. Udagawa, N. Takahashi et al., "Soluble interleukin-6 receptor triggers osteoclast formation by interleukin 6," Proceedings of the National Academy of Sciences of the United States of America, vol. 90, no. 24, pp. 11924-11928, 1993.

[46] N. Kurihara, D. Bertolini, T. Suda, Y. Akiyama, and G. D. Roodman, "IL-6 stimulates osteoclast-like multinucleated cell formation in long term human marrow cultures by inducing IL-1 release," Journal of Immunology, vol. 144, no. 11, pp. 4226-4230, 1990.

[47] Y. Kamagata, N. Miyasaka, H. Inoue, J. Hashimoto, and M. Iida, "Cytokine production in inflamed human gingival tissues-interleukin-6," Nippon Shishubyo Gakkai Kaishi, vol. 31, no. 4, pp. 1081-1087, 1989.

[48] M. Geivelis, D. W. Turner, E. D. Pederson, and B. L. Lamberts, "Measurements of interleukin-6 in gingival crevicular fluid from adults with destructive periodontal disease," Journal of Periodontology, vol. 64, no. 10, pp. 980-983, 1993.

[49] Y. Ishimi, C. Miyaura, C. H. Jin et al., "IL-6 is produced by osteoblasts and induces bone resorption," Journal of Immunology, vol. 145, no. 10, pp. 3297-3303, 1990.

[50] D. G. Perala, R. J. Chapman, J. A. Gelfand, M. V. Callahan, D. F. Adams, and T. Lie, "Relative production of IL-1 beta and TNF alpha by mononuclear cells after exposure to dental implants," Journal of Periodontology, vol. 63, no. 5, pp. 426-430, 1992.

[51] R. T. Kao, D. A. Curtis, D. W. Richards, and J. Preble, "Increased interleukin-1 beta in the crevicular fluid of diseased implants," The International Journal of Oral \& Maxillofacial Implants, vol. 10, no. 6, pp. 696-701, 1995.

[52] D. G. Remick, "Cytokines: a primer for plastic surgeons," Annals of Plastic Surgery, vol. 35, no. 5, pp. 549-559, 1995.

[53] R. J. Lazzara and S. S. Porter, "Platform switching: a new concept in implant dentistry for controlling postrestorative crestal bone levels," International Journal of Periodontics and Restorative Dentistry, vol. 26, no. 1, pp. 9-17, 2006.

[54] H. Baumgarten, R. Cocchetto, T. Testori, A. Meltzer, and S. Porter, "A new implant design for crestal bone preservation: initial observations and case report," Practical Procedures \& Aesthetic Dentistry, vol. 17, no. 10, pp. 735-740, 2005. 
[55] E. Jimi, I. Nakamura, L. T. Duong et al., "Interleukin 1 induces multinucleation and bone-resorbing activity of osteoclasts in the absence of osteoblasts/stromal cells," Experimental Cell Research, vol. 247, no. 1, pp. 84-93, 1999.

[56] K. Kobayashi, N. Takahashi, E. Jimi et al., "Tumor necrosis factor $\alpha$ stimulates osteoclast differentiation by a mechanism independent of the ODF/RANKL-RANK interaction," Journal of Experimental Medicine, vol. 191, no. 2, pp. 275-285, 2000. 


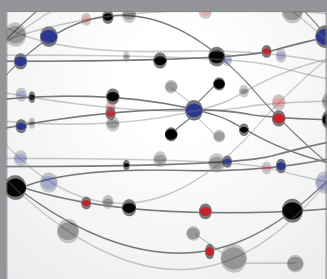

The Scientific World Journal
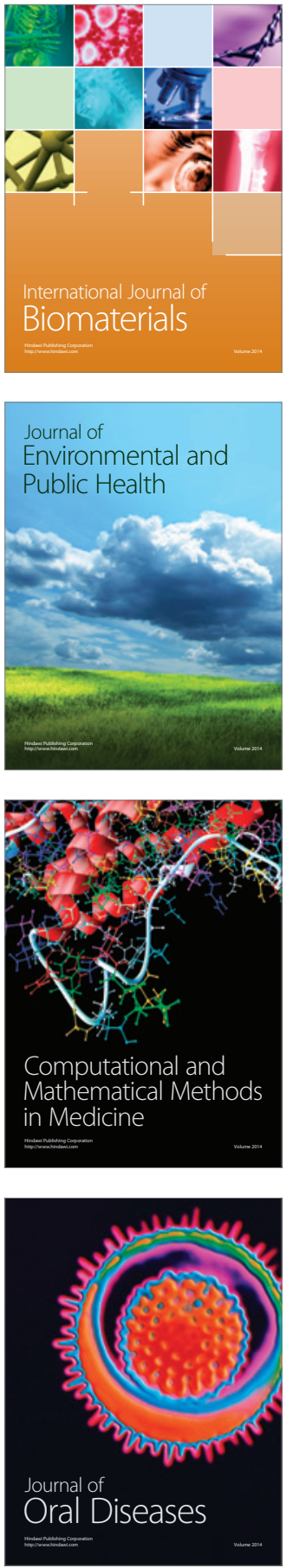
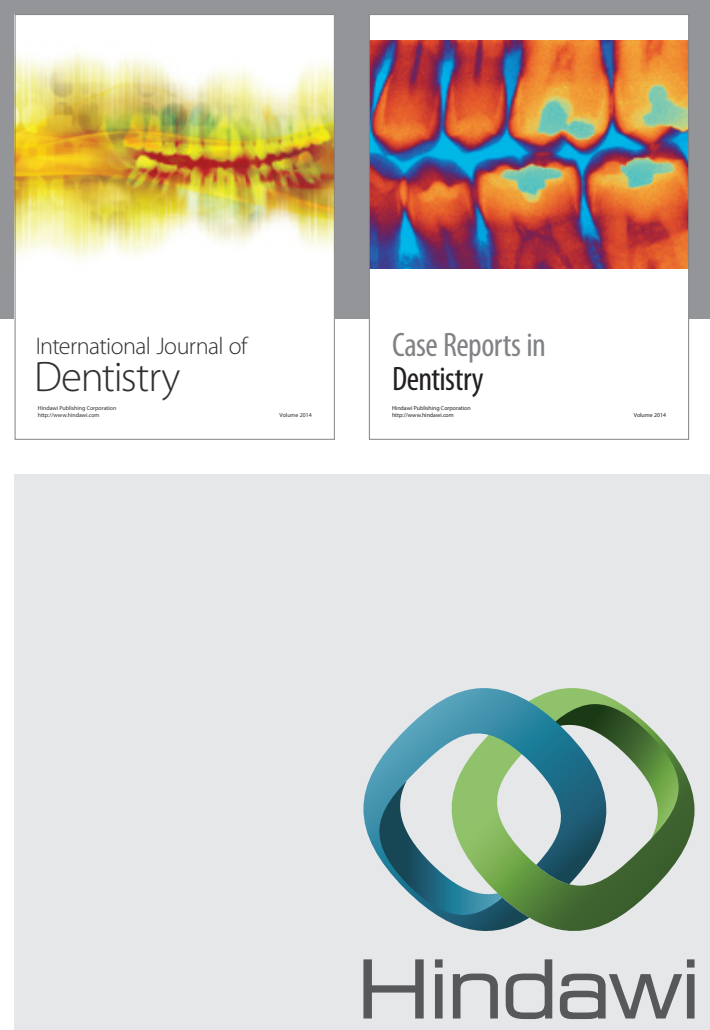

Submit your manuscripts at

http://www.hindawi.com
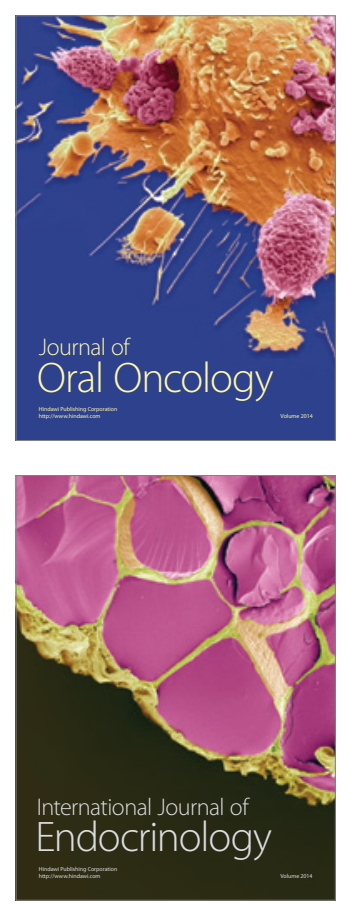
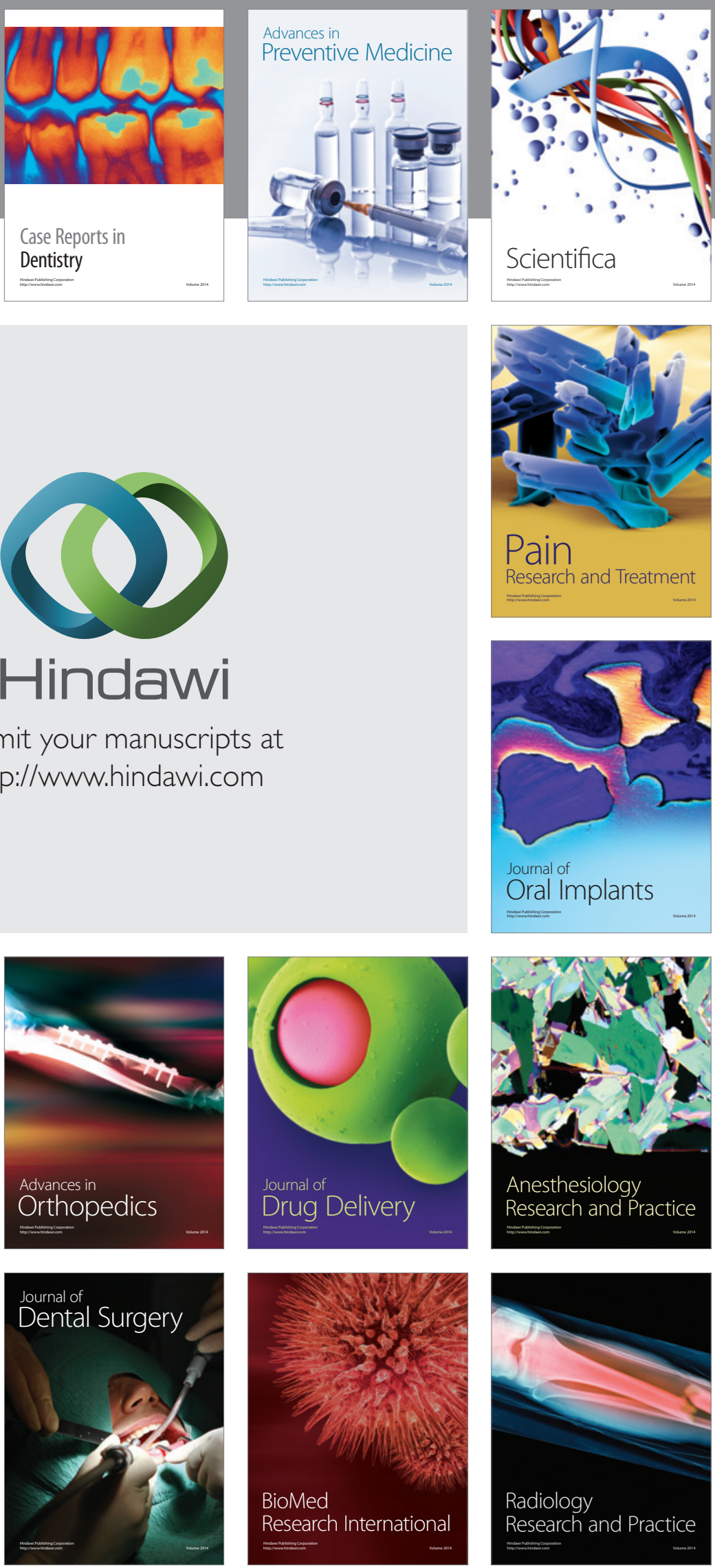